\title{
Determinants of Food Insecurity amongst Primary School Children through the Lens of Affected Parents and Teachers: The Case of Matobo District, Zimbabwe
}

\author{
Nkululeko Joshua Ndiweni \\ Sadhana Manik
}

\begin{abstract}
Children from food insecure households tend to be vulnerable to diseases and miss school or fail to participate in school activities. This paper reports on the determinants of food insecurity amongst primary school children in southwestern Zimbabwe, a context where inadequate data presently exists. According to Chattopadhay (2000: 312), an explanation for Zimbabwe's food insecurity can be understood using the entitlement framework by Amartya Sen (1981). Qualitative research using a case study research design was used. School administrators, teachers and parents of food insecure children were purposively selected. The tools were semi-structured interviews (28 in total) and focus group discussions (14 in total for the six schools that were sampled). The results show that the determinants of food insecurity amongst primary school children in Matobo district are multifaceted: social, economic and environmental and they tend to compound each other. Most households are vulnerable to food insecurity as a result of a loss or lack of physical, social, financial, natural and human assets. Additionally, poverty and climate change seem to be the major contributors of food insecurity in rural areas. The paper concludes by asserting that government can ensure food security in southern Zimbabwe by reviving existing irrigation schemes and supporting income generating projects at household level through training and the provision of start-up capital. There is also the need for non-governmental organizations to
\end{abstract}


empower the local residents of Matobo district on the available options to germinate livelihood success and thus ensure future food security for their families.

Keywords: Food insecurity, climate change, climate variability, vulnerability, resilience, livelihoods and food aid

\section{Introduction}

When food insecurity related disasters, such as droughts strike, children are the most affected by experiencing limited access to enough, safe and nutritious food for an active and healthy life (Manyena, Fordham \& Collins 2008). Children from food insecure households are likely to have diets lower in some core foods, such as fruit, vegetables and lean meat (Ramsey, Giskes, Turrell, $\&$ Gallegos 2011) and tend to be vulnerable to diseases and miss school or fail to participate in school activities. Many of the households in Southern Africa struggle to feed their families due to poverty and an over reliance on climatesensitive livelihoods such as agriculture and natural resources (Murungweni et al. 2014).

Scholes and Biggs (2004) asserted that food insecurity is one element in a cycle of entrenched socio-economic frailty, marked by unemployment, isolation from markets, and lack of education, poverty and vulnerability. Therefore, food insecurity results from a complex interaction of multiple stressors (Connolly-Boutin \& Suit 2015). Amartya Sen noted in the early 1980s that people often fall prey to food insecurity not because food is unavailable on the market but rather because they have limited access (entitlements-failure) to such food caused by poverty (Legwegoh \& Fraser 2015). The poor lack of income results in the inability to access food or to buy inputs for food production. This implies that food insecurity affects those who do not have the means to buy food. Food insecurity is a function of entitlements and not food availability as such (Sen 1981). The poorest populations are normally found in marginal areas that are sensitive to climate change and they tend to rely on climate-sensitive livelihoods. People living in geographically disadvantaged regions are more likely to face unemployment, or have a low income and experience financial problems as a result of a combination of environmental 
and structural barriers (Lê, Auckland, Nguyen, Murray, Long \& Terry 2015). For households to be food secure they need to possess assets essential to their livelihood strategies, that is, human capital, natural capital, financial capital, social capital and physical capital (Matshe 2009).

\section{Drivers of Food Insecurity in Zimbabwe}

In this section, food insecurity is linked to urbanization, social stratification as well as its impacts on childhood development. These focuses are needed, as they are seminal in the context of the study upon which this paper is based.

\section{Urbanization and Rurality's Link to Poverty}

A central argument is that development favours urban areas as economic elites garner political power in the cities and formulate policy to their advantage leaving rural areas undeveloped (Scanlan 2003:103). Urban areas are the core regions and rural areas are the periphery regions. All the resources, some coming from the periphery, are channeled towards the development of the core. This policy favours economic investment in urban areas and disfavours the rural agrarian lifestyle (Scanlan 2003). Rural areas remain underdeveloped and they are engulfed by poverty, which leads to food insecurity. According to Scanlan (2003:103) state commodity boards purchase agricultural products from farmers at artificially low costs and export it for profit, this is a practice to redistribute wealth from the poor rural sector to the cities. Those who produce food are the least able to afford it and are the most likely candidates for hunger from the poverty created by urban bias (Scanlan 2003:103). Uneven distribution of wealth causes underdevelopment, poverty and food insecurity in rural areas.

The road network in Zimbabwe is undeveloped especially in rural areas. Access to markets and utilities is constrained by a lack of infrastructure and prohibitive high-transport costs (Haile 2005:2172). It is very expensive for farmers to access agricultural inputs such as seeds and fertilisers and this compromises production and farmers cannot get their produce to markets at a competitive price due to high transport costs (Haile 2005:2173). It has been observed that access to markets is particularly important for food security since the ability to purchase food is also a major factor in ensuring food security 
(Sunderland 2011:269). Food insecurity in rural areas is also attributable to a lack of appropriate storage facilities. High post-harvest agricultural losses are experienced due to poor storage facilities thereby affecting food stability. All these contribute to the underdevelopment of rural areas.

\section{Social Stratification}

Society is stratified into various classes and this leads to uneven distribution of resources and marginalized groups are affected by food insecurity. Poor people are highly affected by food insecurity as they lack resources to access food. Absolute poverty in particular is a primary indicator of food insecurity (FAO 1999 cited by Scanlan 2003:104). Most societies in sub-Saharan Africa are patriarchal. Additionally, women and girls are discriminated against and fail to access food leading to malnutrition and related health problems (Bennett 1987; Charlton 1984 cited by Scanlan 2003).

The Zimbabwean culture is also patriarchal in nature and it discriminates against women in terms of employment and access to entitlements such as land. Paid off-farm activities are a form of entitlement, however, men and women have differential access (Kerr 2005). According to Kerr (2005:63) women have fewer options for earning off-farm cash income due to employer bias, low education and household duties and some men who are involved in off-farm jobs do not send regular remittances back home. However, women are the most involved in food production, processing, preparation and childcare responsibilities. Economically, women's dependency on men, their unequal access to resources, opportunities and assets, including land, often places them at high risk of HIV/AIDS infection (Gillespie $\&$ Kadiyala 2005:1283). Women and girls make up almost 57\% of all people infected with HIV in sub-Saharan Africa and 76\% of young people (aged 15 24 years) living with HIV are female (UNAIDS cited by Gillespie \& Kadiyala 2005:1283).

HIV/AIDS is a scourge in sub-Saharan Africa and the highest global rates of HIV infection and AIDS related deaths are in Africa, especially in southern Africa (Hamid 1994:255). Research has found that the poor and orphans tend to engage in unsafe sexual behaviours (Mkhonta 2018) and end up contracting HIV/AIDS. The poor despite knowing of the risks, were found to continue engaging in high-risk behaviours, such as seasonal migration 
(Gillespie \& Kadiyala 2005:1284).According to Ansell et al. (2009:194) it was observed that in Lesotho, Malawi, Zambia and Zimbabwe HIV/AIDS is the underlying cause of food insecurity. It affects human capital by incapacitating adults to engage in manual labour and to work for money thereby affecting the purchasing power and monetary resources are diverted towards medical care and funerals (Ansell et al. 2009).

The poor are the most vulnerable to climate change because they do not have access to weather forecasts (Musemwa et al. 2015). Wealthier households tend to be more resilient to droughts because they have access to weather forecasts whilst subsistence farmers are the most affected by short-lived droughts even if average rains are good (Mertz et al. 2009). The major offfarm activity in the study area is vending. Most of the households buy vegetables from irrigation farms and also harvest wild fruits to sell at shopping centres. This informal sector is already saturated and the changing and escalating prices are increasingly exposing most households to vulnerability (Hamid 1994).

\section{Food Insecurity and Childhood}

Household food insecurity has experienced a precipitous rise amongst the low income population who are more vulnerable to the health and environmental risks posed by socioeconomic and physical factors (Nord, Margaret \& Steven 2006). This has precipitated nutrition problems and health issues amongst children due to increased hunger and their insufficient access to nutritious food, leading to low academic achievements.

Given that childhood is a unique development period when an individual's main physical, mental, emotional and social development takes place (Manyena et al. 2008) it is surprising that in the existing literature there is a grey area on the determinants of food insecurity in sub-Saharan Africa. The literature written by Western scientists and policy makers contain a consistent narrative that sub-Saharan Africa is facing food insecurity due to climate change and population growth whilst in the African literature food insecurity is due to poverty problems linked with limited access and poor economic conditions (Legwegoh \& Fraser 2015). Sub-Saharan Africa is the poorest region and food insecurity is rife, thereby affecting child development. Food insecurity amongst primary school children may result in sub-optimal 
psychological, academic and physical development, such as lower school achievement, behavior disorders and underweight (Ramsey et al. 2011). Therefore, research focused on the determinants of food insecurity amongst primary school children and how it impacts child development, is long overdue and imperative to undertake.

The study from which this paper derives, sought to address the aforementioned grey area in the literature; hence the objective of the study, upon which this paper leans, is to determine and characterize the determinants of food insecurity amongst primary school children in Matobo district, through the lens of affected parents and school staff. Hence, this paper is based on a key objective of the study namely the determinants of food insecurity amongst primary school children in Matobo District, in south-western Zimbabwe. The remaining sections of this article are structured as follows: the research methodology is provided, followed by the results and discussion of the results and lastly a conclusion.

\section{Theoretical Framework}

This article leans on the entitlement framework by Amartya Sen (1981) and the work on food insecurity by Chattopadhay (2000) who linked the Zimbabwean situation to Sen's framework. Sen (1981) stated that starvation occurs when a person does not have access to enough food, often despite the availability of food for those who can afford it (Gillespie \& Kadiyala 2005; Hamid 1994). There are two types of entitlements, that is, endowments (or owned assets, such as land) and exchange entitlements, which are mediated by social relations (Kerr 2005:61). According to Hanazaki et al. (2013:156) there is direct entitlement (e.g. a family grows its own food or catches its own fish); indirect entitlement (e.g. a family uses income to purchase food) and transfer entitlement (e.g. a family obtains donated food). A family can have all the three entitlements and be food secure or it can lose all of them and be food insecure. Households experience food insecurity when entitlements are disrupted and a household fails to switch to another way of obtaining food (Hanazaki et al. 2013). When households lose their entitlements they become vulnerable to food insecurity even though food is available, that is, food insecurity could exist in the midst of plenty (Chattopadhay 2000). Food insecurity is a result of a lack of entitlements by households to access food; it is not necessarily a result 
of food availability decline per se. According to Sen (1981) explanations that locate the cause of famine in reductions in food supply are less satisfactory than those which attribute famine to the inability of individuals or households to access food through a range of alternative means (Ansell et al. 2014:613).

\section{Context of the Study}

The study was carried out in Matobo district, in Matabeleland South province of Zimbabwe. Matobo is situated in agro-ecological region IV. The average annual temperature is $19.9{ }^{\circ} \mathrm{C}$ and precipitation averages $457 \mathrm{~mm}$. The area experiences a semi-arid climate as it is subject to periodic seasonal droughts and severe dry spells during the rainy season (Meteorological Services Department 2007). The rainy season occurs from November to March. Most of the areas in the district have wetlands, which sustain community gardens during the dry season. Vegetation is dominated by Acacia fleckii, commonly known as black thorn; mopane (Colophospermummopane) and Cactusspp, a dry land plant species (Ndhlovu 2009). There are 72 primary schools in Matobo district. The study areas were specifically limited to Wards 16 and 17 of Matobo district. Figure 1 shows the location of Matobo district in Zimbabwe, and Wards 16 and 17 are indicated in the following map. Convenience sampling was used to sample (select) six primary schools for easy accessibility.

\section{Research Methodology}

A qualitative case study approach was used to determine and characterize the determinants of food insecurity amongst primary school children (Matobo district) through the lens of their parents and teachers given ethical concerns about researching the vulnerable, in this case, children (Liamputtong, 2007). Indeed, this is a limitation of the study but it was weighed against the prospective trauma of interviewing young learners about the food insecurity that they were experiencing. Qualitative research attempts to make sense of, or interpret, phenomena in terms of the meanings people have highlighted (Denzin \& Lincoln 2005; Creswell 2014). Case studies are the preferred approach when 'how' and 'why' (research) questions are to be answered, when the researcher has little control over events, and when the focus is on a current phenomenon in a real-life context (Karin \& Suzanne 2016:71). The case study was thus the chosen strategy as the researcher wanted to know: why are primary school children experiencing food insecurity in Matobo district in Zimbabwe? 
Figure 1: Location of Matobo District in Southwestern Zimbabwe (not drawn to scale). (Adapted from google images.)

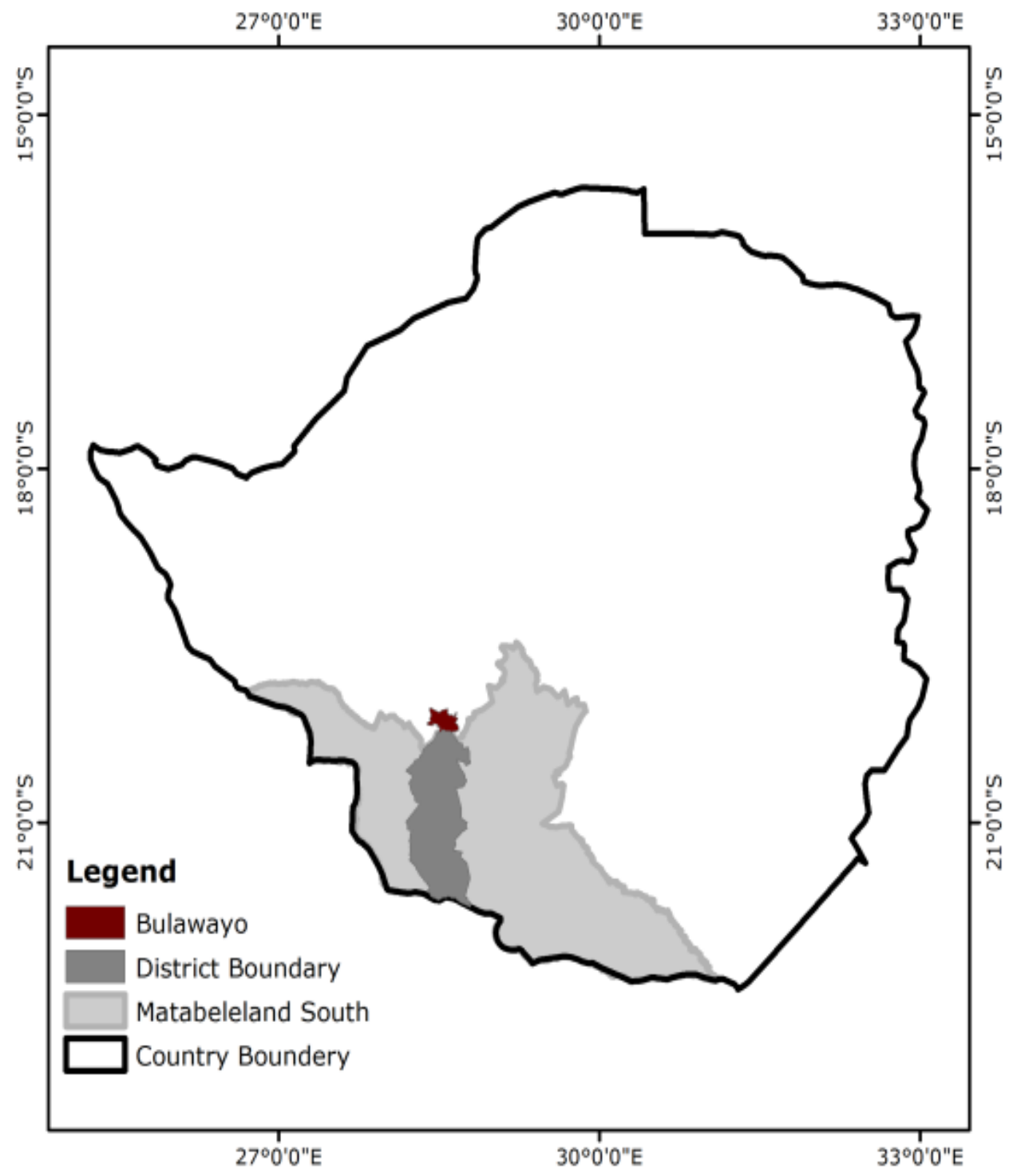


Determinants of Food Insecurity amongst Primary School Children

Figure 2: Location of Ward 17 and Ward 16 in Matobo District (not drawn to scale). (Adapted from google images.)

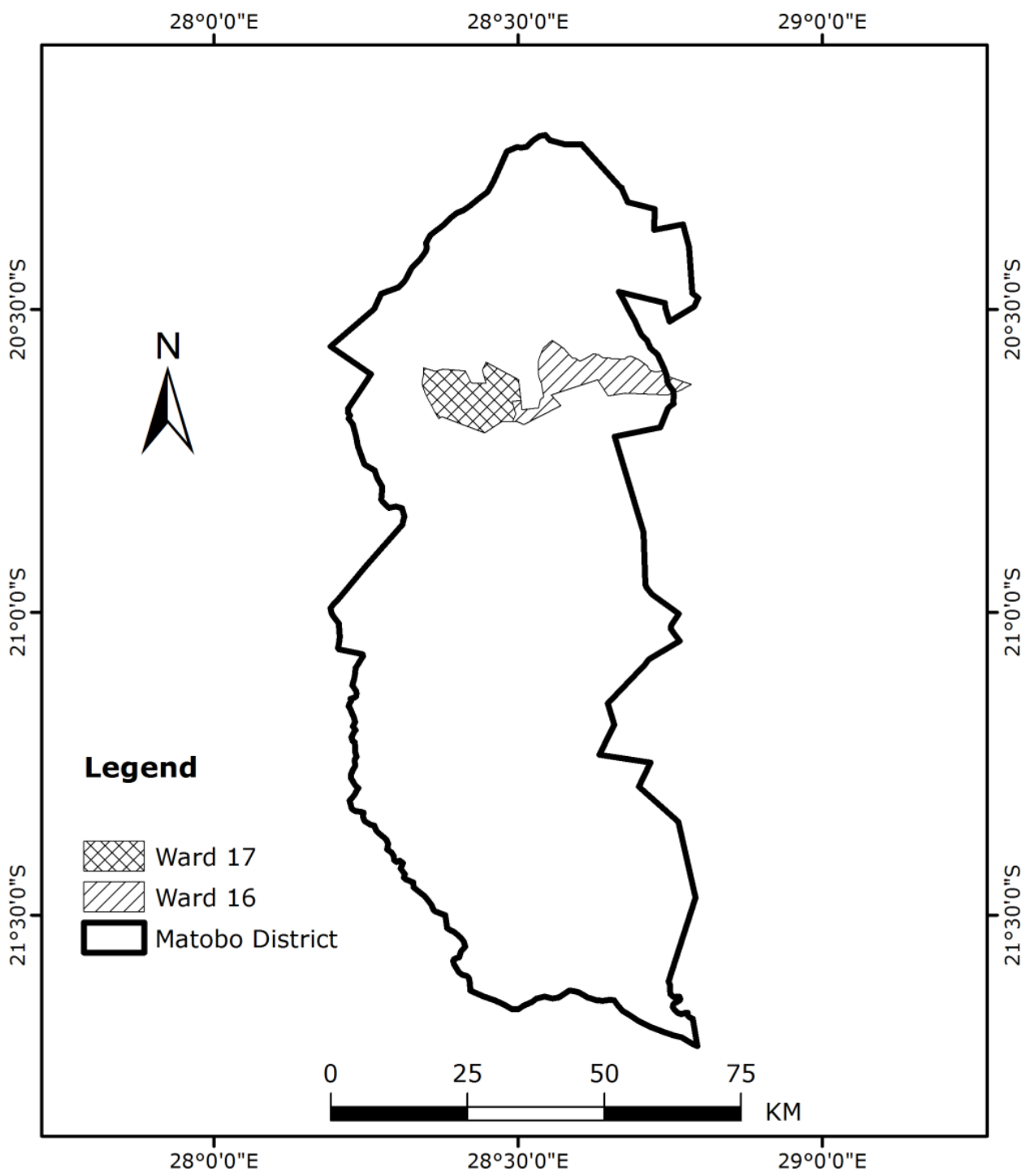


Data was collected from six primary schools through semi-structured interviews and focus group discussions. Semi-structured interviews were used to gather data from two administrators (Principals and H.O.Ds) per school $(n=12)$ who understand the phenomenon of food insecurity in their school contexts and three teachers (of vulnerable children) per school $(n=18$ interviews with teachers) and there was one focus group discussion per school with parents of vulnerable children ( $\mathrm{n}=6$ in total).

Schools were sampled through convenience sampling for easy accessibility, that is, schools located along the main road in the district. In convenience sampling the samples are selected because they are accessible to the researcher (Magwa \& Magwa 2015). Purposive sampling was also used to sample parents and teachers of vulnerable children, and school administrators. These were considered as information-rich sources on determinants of food insecurity in southwestern Zimbabwe. Purposive sampling is exercised to specifically pick information-rich cases linked to the phenomenon of food insecurity, that is, identifying and selecting individuals or groups of individuals that are especially knowledgeable about or experienced with a phenomenon of interest (Bloor \& Wood, 1996 cited in Chattopadhyay 2000; Palinkas et al. 2015). School administrators are more experienced in the system, thus they tend to be knowledgeable about the barriers to education amongst children and they are the link between the school and various stakeholders such as the government and non-governmental organizations providing food aid.

In this study, the data was sub-divided into various meaningful units or themes in relation to the critical questions of the research. The themes that emerged as the determinants of food insecurity include social, economic and environmental issues.

Ethical principles were taken into great consideration. Among the most important ethical principles, the qualitative researcher has to adhere to are informed consent, voluntary participation, confidentiality, protection from harm and maintenance of the well-being of the participants (Karin \& Suzanne 2016:62). The researcher obtained permission from the Provincial and District offices of the Ministry of Education, Sports, Arts and Culture as these are the gatekeepers. Participation in the study was voluntary and the participants were informed that they could withdraw from the study at any time if they chose to do so. The respondents were assured that the data collected would be used solely for research purposes. The researcher outlined the purpose of the study and the approximate time taken to complete each interview, which was 
between 45 - 60 minutes duration. Anonymity was ensured by the use of pseudonyms for all participants and schools so as not to embarrass or harm participants. The researcher did not interview learners but rather their teachers and parents so as to protect them. Preliminary visits were done to make appointments with the participants and convenient times when children were not present were decided upon in advance for the interviews and focus group discussion with parents. Schools offered classrooms to be used for focus group discussions in the afternoons when children were involved in co-curricular activities such as sports. The researcher was assisted by school administrators to invite parents and the parents heeded the call. Staff members were interviewed in their offices for privacy.

The validity of the data was ensured through triangulation of methods; data was generated on the phenomenon using two tools (interviews and focus group discussion) and three separate sources of data (principals, H.O.Ds, parents) to provide a deep understanding of food insecurity being experienced by primary school learners in the Matobo district. The reliability of the study is evidenced in the rich detailed quotations from the participants, presented in this paper.

\section{Findings and Discussion}

The researcher, using thematic content analysis, identified three major determinants of food insecurity amongst primary school learners through the lens of affected parents and teachers: these are social, economic and environmental determinants.

\section{Social Determinants}

Within the theme of social determinants, the link between HIV/AIDS and single parenthood, child-headed households and old age is discussed.

\section{Food Insecurity in Female-headed Households}

Most of the food insecure primary school children or learners have single parents and the major cause of this is HIV and AIDS $(n=12)$. It is difficult for 
single parents, especially women, and sometimes due to ill-health to fend for their children and provide all basic needs by themselves. They tend to rely on begging and also working in other people's homes for long hours as maids or weeding in the fields. The remuneration that they get is very low that it cannot sustain their families. For example, Mrs. Dube explained:

I spent almost five days drinking black tea with my children until my neighbours and the village-head gave me a 10kg bag of mealie-meal. I am a single mother who has two children and I struggle to provide for them. I usually don't know where my next meal will come from. When the situation intensifies I usually get assistance from my neighbours and they always come to my rescue, otherwise my kids would be dead by now.

Ms. Gumede also highlighted that:

We need to be empowered with land as women, but our culture in this country is against the idea. Land is for men not women. If you are not married it becomes difficult to access land.

The above reveals the challenges faced by single-parent mothers in ensuring food security in their households. The patriarchal system is one of the poverty drivers in the community. It leads to feminization of poverty as women are discriminated against in resources such as land. In rural areas agriculture is the main livelihood, therefore, depriving women access to the land and denying them opportunities to learn to farm the land, renders them susceptible to food insecurity. Women now have a double role, which is productive work (to earn a living) and also to be caregivers (of their children) and if they are barred from accessing and creating a livelihood from assets such as the land, then their children bear the brunt in the form of food insecurity.

The health status of the children is also an issue. Children $(n=4)$ from food insecure households are also HIV positive and are further unable to access food in schools which has negative repercussions for their well-being and learning. Mr Ndlovu (principal) explained:

Some of these food insecure children are HIV positive and they come to school on empty stomachs. When they take in ARVs (anti-retroviral 
drugs for HIV treatment), they become very weak to hunger and they normally sleep in class or faint as they try to participate in extra curricula activities.

\section{Food Insecurity within Grandparent-headed Families}

$\mathrm{HIV}$ and AIDS has claimed many lives of the economically active people in Zimbabwe. Most of the learners $(n=15)$ who are food insecure have lost one or both parents due to HIV and AIDS and they live with their grandparents. The grandparents are no longer economically active in various livelihood options and thus do not have access to a regular income and cannot adequately provide food for their children. HIV and AIDS has reduced human capital, which is one of the most important assets of sustainable livelihoods. This shortage of labour in most of the households leads to low productivity. For example, MaKhumalo stated:

I can go for two or three days without eating anything. As an old woman I stay with my grandchildren and their parents are deceased. I get US\$15 per month from Social Welfare as a grant. World Vision also gives us $50 \mathrm{~kg}$ of maize. This does not last us a month because we share with neighbours since everyone is food insecure.

\section{Food Insecurity in Child-headed Families}

Some of the vulnerable learners come from child-headed families with no sustainable source of income $(n=7)$. The major source of income in such families is the trading of wild fruits. Households that rely on this livelihood compete with wild animals such as baboons and monkeys to get wild fruits and the market for these fruits is limited in rural areas. Wild animals also devour their fields during the day and at night. It is difficult for most household members to guard the fields both during the day and at night due to limited human resources. This mostly affects households with single parents, elderly parents and child-headed families. Sitsha (a parent) explained:

It is difficult to earn a living this side of the country. I grow crops for wild animals like baboons and monkeys. These animals also eat our poultry, fruit trees and even our seeds. 


\section{A Dependency Syndrome Leading to Food Insecurity}

The results from the data revealed that food aid has resulted in a dependency syndrome. The interviews with teachers revealed that most of the parents of food insecure learners depend on food aid. The results show that some parents are not involved in income generating projects as they expected World Vision to donate food to the community. Such parents tend to waste a lot of time roaming around the village instead of participating in development projects to build sustainable livelihoods. Mr. Ngwenya a teacher explained:

The problem with people in this area is that they have turned into beggars and receivers of food from Food Aid Programmes. Most of them are lazy and they do not want to stand on their own and support themselves. More so, others have actually stopped their traditional way of surviving such as farming.

Mrs. Sibanda commented:

The community is very much aware that they are food insecure but they do nothing to change this bad situation. What they do is to ask for interventions in terms of food provision from donors. It is now known that this area is for beggars.

It is evident from above that the teachers are firm in their belief that families are unable to survive in Matobo by their own means and are food insecure, because they have become dependent on donor agencies providing food for their survival. Their views are just one perspective and the next section reveals that there are parents who are attempting to ensure that they achieve food security for their families.

\section{Economic Determinants}

It is evident that there are also parents who are making efforts to be financially independent.

\section{Unemployment as a Cause of Food Insecurity}

Nearly all of the learners who are food insecure have unemployed parents and 
guardians. These households find it difficult to access food as they lack financial resources.

Mrs Gangeni explained:

Our children working in South Africa are struggling to make ends meet because of the weakening of the Rand against the US\$. They are finding it hard to put food on the table and there is high unemployment in Zimbabwe. We will die of hunger.

Mr Jubane also explained:

Last season I failed to buy seeds because my children didn't send money home. I heard them saying the Rand is now weak and I don't really know what that means. I'm trying to survive by selling wild fruits and it is no longer profitable as in the past due to climate change and population growth.

Some of the parents are self-employed. They are involved in vending (selling fruits such as mangoes, guavas and wild fruits), wood carving, beekeeping, and thatch grass harvesting. They get less capital from these livelihoods due to a shortage of markets in the rural areas and climate change.

\section{Loss of Livelihoods as a Cause of Food Insecurity}

Most of the parents of learners are slowly losing their livelihoods as a result of climate change. The water-table is gradually falling and rivers quickly dry-up during the winter season making it impossible for irrigation activities. Some of the irrigation schemes are distant from households and this is a great challenge for the elderly and ill parents. Water for irrigation is also very expensive, that is US\$20 per month per household. Most of the fields are now lying idle as the majority of households cannot afford the cost of irrigation. Parents in a focus group discussion highlighted that the quantities of wild fruits have highly plummeted as a result of climate change. They are now competing with wild animals for the few remaining wild fruits and these animals also eat vegetables in gardens because they are not getting enough in the forest. Remittances are 
also no longer a sustainable source of livelihood. Most of the parents $(n=8)$ who have children and relatives in South Africa highlighted that they no longer get remittances as frequently as in the past due to the weakening of the rand against the United States dollar (mostly used in Zimbabwe) and high unemployment. Thatch grass harvesting is also no longer sustainable because of successive droughts, veld fires and population growth. During the Fasttrack-land reform people were settled in areas that produce a lot of thatch grass and illegal gold panners are the major culprits in veld fires. Some households are gradually losing their livelihoods due to climate change and population growth and women were discriminated against during the land reform program. Also, some parents were reluctant to be resettled as they were emotionally attached to their home. Mr. Tshuma explained the loss of livelihood:

In the past we used to harvest thatch grass and mopane worms for sale so as to get cash and access food whenever there was low output in the fields. Nowadays we no longer have mopane worms and thatch grass and we are now competing for the few remaining natural resources. Climate change has greatly affected our livelihoods'

Mrs. Ntini stated:

Households that manage to harvest from their fields and gardens tend to sell their produce on credit due to shortage of markets. Buyers take a lot of time to pay and do not even pay back. This is one of the challenges affecting these farmers.

The above reveals that productive assets such as mopane worms and thatch grass are dwindling as a result of climate change. The increase in aridity leads to the disappearance of bio-resources. Some farmers are compelled by desperation to sell their harvests on credit, which has negative repercussions for families. They tend to lose-out as some clients fail to pay for the goods that they have taken on credit. Most of the participants in the study said climate change is the major cause of food insecurity in the area. Climate change has depleted pastures leading to a loss of livestock and there is a shortage of irrigation water. Successive droughts lead to low agricultural output thereby worsening food insecurity. A Headmaster (Principal of school) stated: 
There is a serious shortage of food in this area which emanates from a number of issues, amongst which are prolonged and chronic shortage of resources. People in this area are chronically hungry and they starve since some go for days without eating anything.

Mr. Bhanko explained in detail:

The situation has been worsened by the fact that the adaptation capacity has been weakened by both climate change and economic hardships in the country. Due to prolonged droughts, the area has lost one of the most valuable natural resources, that is, the mopane worms. People used to generate income from these worms so as to access food.

\section{A Shortage of Farming Inputs Resulting in Food Insecurity}

Most of the learners come from households where agricultural production is very low. A shortage of inputs was identified as one of the causes of low productivity. Unemployment and loss of livelihoods lead to shortage of financial capital thereby causing poverty, this ultimately hinders households from accessing agricultural inputs, and the result is chronic food insecurity. Most households lack a means of production because of poverty. For example. Mr. Simela stated:

I'm very poor, I don't have draught animals, I don't have farming inputs and my piece of land is very small. I usually assist those who have draught animals but they come to plough my fields very late towards the end of the planting time, so I don't benefit much. I normally practice organic farming but it is very labour intensive, it needs young people who have a lot of energy.

The above quote reveals a number of factors that affect food insecurity from a farmer's perspective.

\section{Small Land Holdings}

Matobo district is mountainous making it difficult for crop production. Most households have small pieces of land and they cannot sustainably practice crop 
production. The mountains in the area are also a habitat for wild animals like baboons, monkeys, wild pigs and leopards, which are pests to crops and livestock. Households thus find it difficult to practice agriculture due to small pieces of land and animals destroying crops and killing their livestock.

Mr. Nyathi explained this:

Our area is full of rocks and this minimizes land for crop production, and the few crops that we grow are eaten by baboons. We cannot keep goats and poultry because they are eaten by baboons and leopards. These are some of the causes of hunger in our area.

Matobo district is in a semi-arid environment. Most of the farmers grow drought tolerant crops such as millet and sorghum, however, the greatest challenge are quelea birds that feed on these small grains. Households try to guard their fields against animals and birds but this is a very demanding exercise for the elderly and ill parents. Some learners fail to go to school as they will be manning the fields and this compromises their learning.

\section{Figure 3: Determinants of food insecurity in Matobo District}

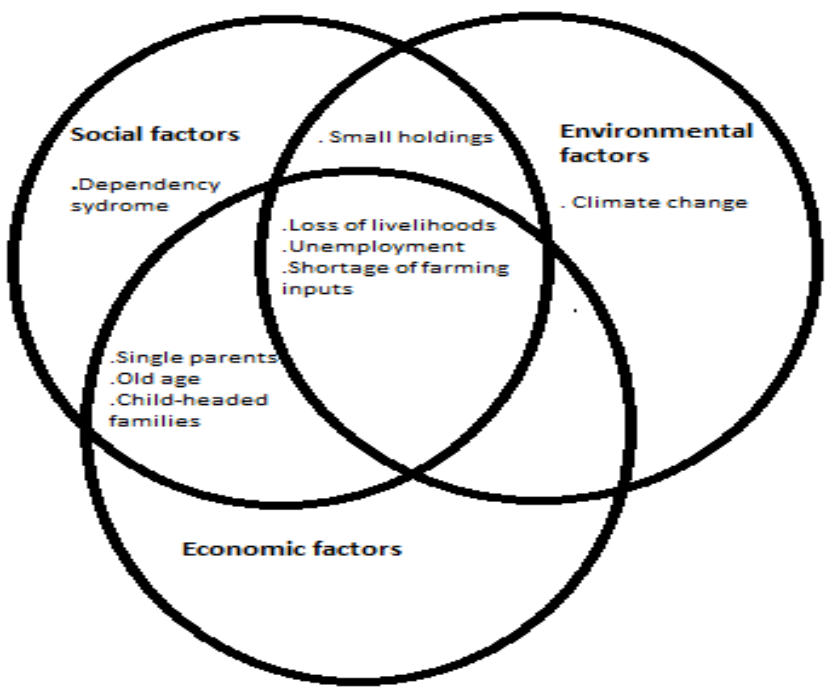




\section{Discussion}

The results of the study show that there are three major causes of food insecurity, albeit they are interrelated as we show and annotate this in figure 2, above. Loss of livelihoods, unemployment and a shortage of farming inputs are social, environmental and economic determinants. Single parents, old age and child-headed families are social and economic determinants of food security. Lastly, a small holding is both a social and environmental determinant.

\section{Multiple Intersecting Determinants of Food Insecurity: A Dearth of the Five Livelihood Assets}

The following section discusses how the various capitals interact leading to food insecurity in Matobo district: human, natural, financial, social and physical capitals.

\section{Demographic and Health Determinants of Food Insecurity}

The results reveal that most of the learners who are food insecure have single parents or guardians who are economically inactive due to ill-health and/or old age. The majority of single parents ( $\mathrm{n}=$ twelve) are women who have lost their partners due to HIV/AIDS. The study revealed that food insecurity is rife in women-headed households due to ill health and a lack of access to livelihood assets (such as land, seeds, fertilizers, credit facilities) due to gender-biased traditions. Studies have shown that in southern Africa, 58 percent of the HIV/AIDS affected people are women and this threatens food security, as most women are involved in agricultural production. Female-headed households often have lower adaptive capacity due to their limited access to economic resources and this is mostly a result of social discrimination (Agarwal cited by Cramer et al. 2016). These households are food insecure due to shortage of labour, loss of assets and skills, adult mortality and the increased burden of care (Ansell et al. 2009) which was also evident in the present study. Consistent with the findings of this study, are the results of the study that was carried out in Australia by Ramsey et al. (2011) which revealed that a higher proportion of single parent households are food insecure. Assets such as livestock are sold to purchase medicine or cover other illness-related costs and this increases 
household vulnerability to food insecurity. The gathering of wild foods or engaging in casual and migrant labour becomes problematic due to a shortage of labour, farming skills are lost, livelihoods disintegrate and household earnings shrink thereby causing food insecurity (Ansell et al. 2009; Clover 2003).

HIV/AIDS has also increased the number of child-headed families that are very poor. Additionally, poverty is a result of loss of property (endowment) when parents die as was also evident in this present study. Children do not have the necessary knowledge, skills and time to farm the land if they are expected to attend school. Mbaya (2002 cited by Ansell et al. 2009) also alluded to the loss of land and livestock as well as farming equipment being sold to fund medical and funeral costs or items being misappropriated by relatives. A loss of entitlements clearly exposes children to food insecurity. Ansell et al. (2009) also found that those children who inherit land are too young or inexperienced to farm it, since children acquire livelihood skills by working with older kin. The unexpected death may interrupt intergenerational knowledge transfer and they report that many children withdraw from school to address labour shortages. Some of the orphans end up engaging in unsafe sexual behaviours and contracting HIV/AIDS due to food insecurity and the lack of guidance from adults. The relationship of HIV/AIDS to food insecurity was found to be bidirectional: vulnerability and food insecurity feed into the very risky behaviour that drives the HIV/AIDS pandemic, and the impact of HIV/AIDS exacerbates food insecurity, which again feeds into risk (Clover 2003:12). Child headed families fail to access food in the market, due to a limited access to gainful off-farm employment opportunities and income-generating activities (Moyo 2007). The underdevelopment of rural areas as is the case of Matobo is also limiting the opportunities for generating sufficient income for accessing food.

\section{The Nexus of Poverty and Food Insecurity}

Poverty is the key determinant of food insecurity with a high potential of amplifying people's vulnerability (Bele, Sonwa \& Tiani 2014). The present study indicates that the impacts of social and environmental determinants of food insecurity are exacerbated by poverty. Food insecure children come from poor households. Unemployment, a loss of livelihoods and a shortage of 
markets lead to low income, poverty and ultimately failure to access food. The findings of Manyena, Fordham and Collins (2008) concur with the findings of this study in that food insecurity is a result of a lack of assets (especially entitlements such as the ability to grow your own crops for your own needs) which could be converted to money to enable families to access food. Insufficient financial capital hinders families from accessing sufficient foods that are consistent with dietary recommendations for health and well-being (Ramsey et al. 2011). It was observed that although some participants had endowments, such as land, they were still food insecure due to several factors. These included but were not limited to climate change impacts such as the costs of irrigation for the semi-arid Matobo district, inadequate farming knowledge, an inability to farm the land due to biographical reasons such as youth/old age. Interestingly, in Sudan, people chose to go hungry in order to preserve their assets and their future livelihood; they chose not to consume food rather than sell their vital assets (de Waal, 1990 cited by Molnar 1999). This means that some households can own other entitlements (livestock) and be food insecure, which is contrary to Amartya Sen's observation.

\section{The Feminization of Food Insecurity}

At the household level, women play a major role in the provision of food security for their families. However, most of the food insecure families are very poor and women head them. It has long been reported that families headed by women are food insecure due to poverty, discrimination, divorce and longer life expectancy (Molnar 1999). In the present study, a lack of entitlements by women is necessitated by cultural values and attitudes which are patriarchal and which treat women as minors. According to Mutopo (2011:1029), most women in Zimbabwe do farm their husbands' land but they do not have any form of title to that land, land ownership is patrilocal. Land is viewed as a resource associated with men. During the Fast-Track Land Reform Programme (FTLRP), most women were discriminated along political, social and economic lines (Mutopo 2011). Molnar (1999:492) asserts that cultural factors that repress the role and status of women diminish food security not only for women but also for their children. It has been observed that women are the main farmers but their subordinate cultural and social position often curtails their abilities to farm as productively as possible (Goebel 2005:150). 
Poverty leads to food insecurity thereby reducing the capacity for work and resistance to diseases, and it affects children's mental development and educational achievements (Clover 2003). Studies have shown that when a disaster strikes, the poor and socially disadvantaged are greatly affected and are the least equipped to cope with the impact due to lack of information and resources. However, if women have access to and control over land, family livelihood patterns can improve because most of the women-headed households have better management policies in terms of farming practices, the marketing of the produce and in use of the income (Mutopo 2011:1031). In other words, a matrilineal and matrilocal system in society leads to food security as women would be owners of the land and involved in income decisions (Kerr 2005) but in Zimbabwe, the women would need to be educated about successful farming practices if they have not partaken in significant ways to farming as a livelihood option.

\section{Sustainability of Coping Strategies in Ensuring Food Security}

Families that have livestock tend to sell them off including assets to finance food purchases. However, due to the shortage of markets and available access to markets, they sell them at reduced prices or on credit whilst food prices would be rising. Harvests from the fields and forests and carvings are also sold on credit due to the desperate condition in which the people find themselves. Families tend to get low incomes from these 'trade-offs' and this further exacerbates the vulnerability of the community to food insecurity (Misselhorn 2005). In Zimbabwe, most households are failing to purchase farming inputs because of poverty. It is estimated that in 2002, about $90 \%$ of the 300000 Zimbabweans who were allocated land during the FTLRP lacked farm inputs and $94 \%$ did not have seeds for the upcoming seasons and this reduced output by $75 \%$ from the previous year (Clover 2003). Land reform programmes have enormous potential to increase agricultural production if they are accompanied by comprehensive programmes of agrarian reform including access to credit, savings and markets in rural areas (Clover 2003:10). These findings are consistent with the observation of Amartya Sen (1981) that people starve when they do not have the means to buy food. Ofcourse, if women were made to be the beneficiaries of the land reform in Zimbabwe, this will also have advantaged them and their families. 
Some families in the present study have embarked on various income generating projects such as bee keeping and poultry farming. This is in line with the assertion of Clover (2003) that food insecurity can be prevented by creating public projects to provide income for potential famine victims. However, in the study area just a few households carried out these incomegenerating projects and they were not yet a sustainable livelihood. Parents during a focus group discussion indicated that these projects are a challenge to many households, as they have to follow standard measurements when constructing fowl runs making them impossible to fit in their small yards and the market prices for products were not attractive. In addition to this, for many of the poorest households, projects which generate revenue that are not farm dependent were not viable; indeed Burke \& Lobell (2010) have noted that off farm projects are limited by liquidity or human capital constraints i.e. shortage of cash and skills.

\section{Faulty Government Policies as Determinants of Food Insecurity}

The lack of purchasing power at household level in Zimbabwe is also a result of failure in the political accountability of government and even political interference (Clover 2003). Expropriation of farms and industries in the last decade shunned away investors and a lot of people were retrenched. Scholes and Biggs (2004) cited by Gregory, Ingram and Brklacich (2005) observed that food insecurity in southern Africa in 2002 - 2003 was not a result of climatic factors only but it was a result of regional and global political and economic factors including legacies of structural adjustment, government policies, conflict and war. This implies that some policies work well in other regions and are irrelevant in sub-Saharan Africa. The political environment greatly contributes to food insecurity as witnessed in Zimbabwe but Amartya Sen (1981) did not consider it as a determinant of food insecurity. Sen's (1981) explanations on food insecurity were too apolitical and ahistorical (Ansell et al. 2009). Food insecurity is attributed to the nation states' faulty policies or poor implementation of sound policy (Molnar 1999).

Population growth is associated with human ingenuity (Boserup 1965) and human adaptability is the greatest resource available (Scanlan 2001). However, faulty government policies are a barrier to human ingenuity. According to Scanlan (2001:255) the development of rural areas offsets 
problems of population growth and food insecurity due to better food distribution via transportation networks thus increasing availability of food and reducing access problems. Without rural development, human ingenuity might be very expensive for the poor rural people as experienced in the study area where most of the households cannot afford the expenses associated with irrigation. When human systems fail, repair costs for irrigation systems are much greater, and the ability of a reliable source of water to realise its promise for food is greatly impaired (Molnar 1999:494).

\section{The Role of Climate Change in Food Insecurity}

The study revealed that climate change and variability have intensified poverty as most people have lost their livelihoods and natural resources. The quality of thatch grass is deteriorating and non-timber forest products such as mopane worms are getting scarce, all this is attributed to successive droughts in the district. Most families rely on rain-fed agriculture and harvests are close to none, during times of weather anomalies, for example during droughts. Irrigation water is beyond the reach of many households as surface and ground water sources are shrinking. Climate change has greater effects on those living in poverty as they depend most heavily on climate-sensitive livelihood activities such as agriculture and exploitation of natural resources (Bele, Sonwa \& Tiani 2014). Weather anomalies tend to have devastating effects on most households as they do not have alternative water sources but have to rely on rainfall. Entitlement to water is important for ensuring production throughout the year, however, in a changing climate; diversification of incomes out of agriculture is a plausible adaptation strategy in sub-Saharan Africa (Burke \& Lobell 2010:142).

Sunderland (2011: 266) postulates that around one billion people rely on wild harvested products for nutrition and income and the 'invisible' trade in wild resources is estimated to generate $\$ 90$ billion/annum. Climate change has greatly compromised this viable livelihood in Matobo district. Frequent droughts have reduced the quantity and quality of biodiversity. Local people in Matobo district compete with outsiders (from other districts) in the harvesting of wild products such as fruits, mopane worms and thatch grass. Due to a shortage of food in the forests, wild animals such as baboons and leopards end up invading homesteads and eating chickens and goats. House- 
holds lose important assets as small ruminants provide insurance and a substantial source of income and it helps spread income risk (Douxchamps et al. 2015). According to Songok et al. (2011:76) community food reserves and traditional food storage systems, at household level, should be established in order to empower communities regarding the need to ensure food security at the local level and reduce losses due to poor storage.

Population growth in the district has led to the fragmentation of the land resulting in households having small pieces of land for agricultural activities, which are over cultivated. Over cultivation of land leads to loss of soil fertility which is an essential entitlement for high productivity. Over cultivation leads to soil degradation, which is irreparable environmental damage, as highlighted by the Neo-Malthusian perspectives that population growth will outstrip the earth's ability to provide for its inhabitants (Scanlan 2001:245). Malthus (1798) and Sen (1981) echoed the same sentiments that over population can lead to loss of entitlements and eventually experiences of food insecurity. The largest proportion of the hungry is concentrated amongst the world's landless, or smallholder farmers whose plots are too small for their needs (Matshe 2009). The writer, therefore, theorizes that population growth without sustainable government policies can strain resources (entitlements) and this eventually results in food insecurity. Households in the study area are vulnerable to food insecurity as they lack natural capital, which is a buffer against hunger and famine. Land is an asset and it forms the basis of a household's entitlements (Jesse \& Fellow 1995). Rural households with a sizeable amount of land are better off, in terms of personal welfare, and lesslikely to be poor and food insecure than those with marginal lands or without land (Mlambo 2000 cited by Matshe 2009). The farmers in Matobo have small farmlands that are inadequate for farming. Land is not only used for crop growing but to create other livelihoods like poultry production, wood fuel and edible fruits. Land is the key to survival and feeding one's family (Bele, Sonwa \& Tiani 2014). It is evident that in particular for the children to be food secure in Matobo district, that sufficient fertile land for their families to cultivate and farm is essential.

\section{Conclusion}

The determinants of food insecurity are multi-dimensional in the rural areas of Matobo district; however poverty and climate change seem to be the major 
contributors. Poverty restricts people from diversifying their livelihoods as they will be lacking the five livelihood assets: - that is, human, natural, financial, social and physical capitals. Most of the households become vulnerable to environmental factors as a result of poverty. Climate change and variability also exacerbate food insecurity because most of the rural livelihoods hinge on the availability and affordability of water and fertile adequate land to ensure food security. A shortage of water and fertile land renders almost all rural livelihoods unsustainable thereby intensifying food insecurity. The government can ensure food security in Matobo district, by reviving the existing irrigation schemes and supporting income generating projects at household level through training and providing startup capital rather than a dependency on donor agencies providing food. In a changing climate, to buffer food insecurity in the face of a short-run climate shock, families should diversify their livelihoods by engaging on off-farm activities that are less climatesensitive but they would need interested stakeholders like non-governmental organizations to empower them on the types and scales of the different options.

\section{References}

Ambert, A., P.A. Adler, P. Adler \& D.F. Detzner 1995. Understanding and Evaluating Qualitative Research. Journal of Marriage and Family 574: $879-893$.

https://doi.org/10.2307/353409

Andersson, J.A. 2007. How Much Did Property Rights Matter? Understanding

Food Insecurity in Zimbabwe: A Critique of Richardson. African Affairs 106,425: 681 - 690.

https://doi.org/10.1093/afraf/adm064

Ansell, N., E. Robson, F. Hadju, L. van Blerk \& L. Chipeta 2009. The New

Variant Famine Hypothesis: Moving beyond the Household in Exploring

Links between AIDS and Food Insecurity in southern Africa. Progress in

Development Studies 9, 3: 187 - 207.

https://doi.org/10.1177/146499340800900302

Baro, M. \& T.F. Deubel 2006. Persistent Hunger: Perspectives on Vulnerability, Famine, and Food Security in Sub-Saharan Africa. Annual Review of Anthropology 35: 521 - 538.

https://doi.org/10.1146/annurev.anthro.35.081705.123224 
Bele, M.Y., D.J. Sonwa \& A.M. Tiani 2014. Local Communities' Vulnerability to Climate Change and Adaptation Strategies in Bukavu in DR Congo. Journal of Environment \& Development 23, 3: 331 - 357. https://doi.org/10.1177/1070496514536395

Bradley, J. 1993. Methodological Issues and Practices in Qualitative Research. Symposium on Qualitative Research: Theory, Methods, and Applications 634: 431 - 449.

Burke, M. \& D. Lobell 2010. Food Security and Adaptation to Climate Change: What do we Know? In Lobell, D. \& M. Burke (eds.): Climate Change and Food Security: Adapting Agriculture to a Warmer World. London: Springer.

Chattopadhyay, R. 2000. Zimbabwe: Structural Adjustment, Destitution and Food Insecurity. Review of African Political Economy 27, 84: 307 - 316. https://doi.org/10.1080/03056240008704461

Choudhary, N. \& D. Parthasarathy 2007. Gender, Work and Household Food Security. Economic and Political Weekly 42, 6: 523 - 531.

Cliffe, L., J. Alexander, B. Cousins \& R. Gaidzanwa 2011. An Overview of Fast Track Land Reform in Zimbabwe: Editorial Introduction. The Journal of Peasant Studies 38, 5: 907 - 938.

https://doi.org/10.1080/03066150.2011.643387

Clover, J. 2003. Food Security in sub-Saharan Africa. African Security Review 12, 1: $5-15$.

https://doi.org/10.1080/10246029.2003.9627566

Connolly-Boutin, L. \& B. Smit 2015. Climate Change, Food Security, and Livelihoods in sub-Saharan Africa. Regional Environmental Change 16: 385 - 399. https://doi.org/10.1007/s10113-015-0761-x

Creswell, J. W. 2014. Research Design. London: SAGE Publications, Inc. Denzin, N.K., \& Y.S. Lincoln 2005. The Sage Handbook of Qualitative Research. $3^{\text {rd }}$ Edition. Thousand Oaks, CA: Sage.

Douxchamps, S., M.T. van Wijk, S. Silvestri, A.S. Moussa, C. Quiros, N.Y.B.

Ndour, S. Buah, L. Some, M. Herrero, P. Kristjanson, M. Ouedraogo, P.K.

Thornton, P. van Asten, R. Zougmore, \& M.C. Rufino 2015. Linking Agricultural Adaptation Strategies, Food Security and Vulnerability: Evidence from West Africa. Regional Environmental Change 16: 1305 1317. https://hdl.handle.net/10568/52329

Gillespie, S. \& S. Kadiyala 2005. HIV/AIDS and Food and Nutrition Security: Interactions and Response. American Journal of Agricultural Economics 
Nkululeko Joshua Ndiweni and Sadhana Manik

87, 5: 1282 - 1288.

https://doi.org/10.1111/j.1467-8276.2005.00820.x

Gregory, P.J., J.S.I. Ingram \& M. Brklacich 2005. Climate Change and Food

Security. Philosophical Transactions: Biological Sciences 360, 1463:

2139 - 2148.

https://doi.org/10.1098/rstb.2005.1745

Goebel, A. 2005. Zimbabwe's 'Fast Track' Land Reform: What about

Women? Gender, Place \& Culture 12, 2: 145 - 172.

https://doi.org/10.1080/09663690500094799

Haile, M. 2005. Weather Patterns, Food Security and Humanitarian Response

in Sub-Saharan Africa. Philosophical Transactions: Biological Sciences 360, 1463: 2169 - 2182.

https://doi.org/10.1098/rstb.2005.1746

Hamid, B.A. 1994. Availability, Affordability and Accessibility of Food in

Khartoum. GeoJournal 34, 3: 253 - 255.

https://doi.org/10.1007/BF00813927

Hanazaki, N., F. Berkes, C.S. Seixas \& N. Peroni 2013. Livelihood Diversity,

Food Security and Resilience among the Caiçara of Coastal Brazil.

Human Ecology 41, 1: 153 - 164.

https://doi.org/10.1007/s10745-012-9553-9

Hancock, B. 1998. Trent Focus for Research and Development in Primary

Health Care: An Introduction to Qualitative Research. Nottingham: Trent Focus Group.

Karin, K. \& M. Suzanne 2016. Qualitative Research in the Study of Leadership. $2^{\text {nd }}$ Edition. Bingley: Emerald Group Publishing Limited.

Kerr, R.B. 2005. Food Security in Northern Malawi: Gender, Kinship Relations and Entitlements in Historical Context. Journal of Southern African Studies 31, 1: 53 - 74.

https://doi.org/10.1080/03057070500035679

Lê, Q., S. Auckland, H.B. Nguyen, S. Murray, G. Long \& D.R. Terry. 2015.

The Socio-Economic and Physical Contributors to Food Insecurity in a Rural Community. Sage Open 5,1.

DOI $10.1177 / 2158244014567401$

Legwegoh, A.F. \& E.D.G Fraser. 2015. Food Crisis or Chronic Poverty:

Metanarratives of Food Insecurity in Sub-Saharan Africa. Journal of Hunger \& Environmental Nutrition 10, 3: 313 - 342.

https://doi.org/10.1080/19320248.2014.962777 
Liamputtong, P. 2007. Researching the Vulnerable: A Guide to Sensitive Research Methods. Michigan: Sage.

https://doi.org/10.4135/9781849209861

Magwa, S. \& W. Magwa. 2015. A Guide to Conducting Research: A Student Handbook. Singapore: Strategic Book Publishing and Rights Co.

Manyena, S.B., M. Fordham \& A. Collins 2008. Disaster Resilience and Children: Managing Food Security in Zimbabwe's Binga District. Children, Youth and Environments 18, 1: 303 - 331.

Matshe, I. 2009. Boosting Smallholder Production for Food Security: Some Approaches and Evidence from Studies in sub-Saharan Africa. Agrekon 48, 4: 483 - 511.

https://doi.org/10.1080/03031853.2009.9523837

Mertz, O., C. Mbow, A. Reenberg \& A. Diouf 2009. Farmers' Perceptions of Climate Change and Agricultural Adaptation Strategies in Rural Sahel. Environmental Management 43:804 - 816.

https://doi.org/10.1007/s00267-008-9197-0

Misselhorn, A.A. 2005. What Drives Food Insecurity in southern Africa? A

Meta-analysis of Household Economy Studies. Global Environmental Change 15:33 - 43.

https://doi.org/10.1016/j.gloenvcha.2004.11.003

Molnar, J. J. 1999. Sound Policies for Food Security: The Role of Culture and Social Organization. Review of Agricultural Economics 21, 2: 489 - 498. Moriarty, J. 2011. Qualitative Methods Overview. London: NIHR School for Social Care Research.

Moyo, D. 2007. The Future of Food: Elements of Integrated Food Security Strategy for South Africa and Food Security Status in Africa. Proceedings of the Annual Meeting (American Society of International Law) 101: 103 - 108. Available at: www.jstor.org/stable/25660167

Murungweni, C., M.T. van Wijk, K.E. Giller, J.A. Andersson \& E.M.A. Smaling 2014. Adaptive Livelihood Strategies Employed by Farmers to Close the Food Gap in Semi-arid South Eastern Zimbabwe. Food Security 6: 313 - 326.

https://doi.org/10.1007/s12571-014-0348-2

Musemwa, L., V. Muchenje, A. Mushunje, F. Aghdasi \& L. Zhou 2015. Household Food Insecurity in the Poorest Province of South Africa: Level, Causes and Coping Strategies. Food Security 7: 647 - 655. https://doi.org/10.1007/s12571-015-0422-4 
Mutopo, P. 2011. Women's Struggles to Access and Control Land and Livelihoods after Fast Track Land Reform in Mwenezi District, Zimbabwe. The Journal of Peasant Studies 38, 5: 1021 - 1046.

https://doi.org/10.1080/03066150.2011.635787

Nord, M., A. Margaret \& C. Steven 2006. Household Food Security in the United States, 2005, ERR-29. USA: Economic Research Service.

Oliver, G. 2004. Investigating Information Culture: A Comparative Case Study

Research Design and Methods. Archival Science 4, 3-4: 287 - 314.

Ramsey, R., K. Giskes, G. Turrell \& D. Gallegos 2011. Food Insecurity among Australian Children: Potential Determinants, Health and Developmental Consequences. Journal of Child Health Care 15, 4: 401 - 416.

https://doi.org/10.1177/1367493511423854

Richardson, C.J. 2007. How Much Did Droughts Matter? Linking Rainfall and GDP Growth in Zimbabwe. African Affairs 106:424: 463 - 478.

https://doi.org/10.1093/afraf/adm013

Scanlan, S.J. 2003. Food Security and Comparative Sociology: Research, Theories, and Concepts. International Journal of Sociology 33, 3: 88 111.

https://doi.org/10.1080/15579336.2003.11770272

Scanlan, S.J. 2001. Food Availability and Access in Lesser-Industrialized Societies: A Test and Interpretation of Neo-Malthusian and Technoecological Theories. Sociological Forum 16, 2: 231 - 262. https://doi.org/10.1023/A:1011000717740

Scholes, R.J., \& R. Biggs 2004. Ecosystem Services in Southern Africa: A Regional Assessment. Pretoria, South Africa: Council for Scientific and Industrial Research

Sen, A. 1981. Poverty and Famines: An Essay on Entitlement and Deprivation. Oxford: Oxford University Press.

Songok, C.K., E.C. Kipkorir \& E.M. Mugalavai 2011. Integration of Indigenous Knowledge Systems into Climate Change Adaptation and Enhancing Food Security in Nandi and Keiyo Districts, Kenya. In Filho, W.L. (ed.): Experiences of Climate Change Adaptation in Africa (65 95). London: Springer.

Sunderland, T.C.H. 2011. Food Security: Why is Biodiversity Important? The International Forestry Review 13, 3: 265 - 274.

https://doi.org/10.1505/146554811798293908

Yin, R.K. 2012. Applications of Case Study Research. London: Sage. 
Determinants of Food Insecurity amongst Primary School Children

Nkululeko Joshua Ndiweni

Lupane State University

Zimbabwe

njndiweni@gmail.com

Sadhana Manik

Geography Education

University of KwaZulu-Natal

manik@ukzn.ac.za 